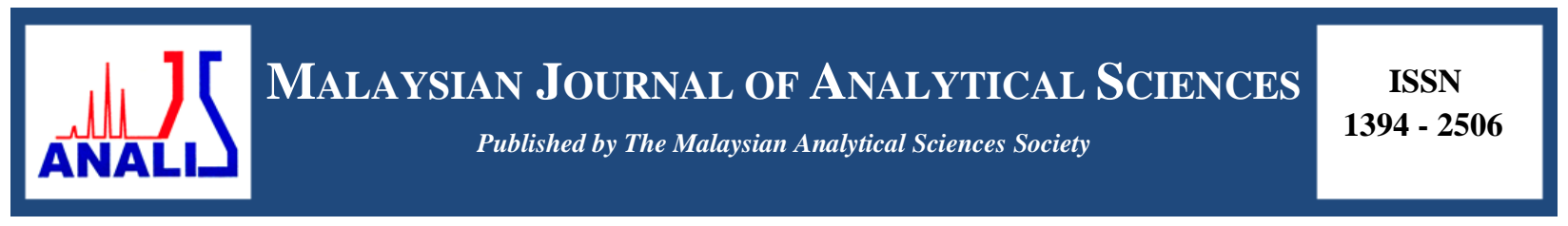

\title{
A NEW ULTRA VIOLET-VISIBLE SPECTROPHOTOMETRIC METHOD FOR QUANTITATIVE DETERMINATION OF ACRYLAMIDE VIA HYDROLYSIS PROCESS
}

\author{
(Kaedah Spektrofotometrik Ultra Violet-Cahaya Nampak Baharu untuk Penentuan Akrilamida \\ Secara Kuantitatif Melalui Proses Hidrolisis) \\ Yee-May Chong ${ }^{1}$, Musa Ahmad ${ }^{2}$, Lee Yook Heng ${ }^{1}$ \\ ${ }^{I}$ School of Chemical Sciences and Food Technology, Faculty Sciences \& Technology, \\ Universiti Kebangsaan Malaysia, 43600 UKM Bangi, Malaysia \\ ${ }^{2}$ Industrial Chemical Technology Programme, Faculty Sciences \& Technology, \\ Universiti Sains Islam Malaysia, 71800 Nilai, Malaysia \\ *Corresponding author: andong@usim.edu.my
}

Received: 5 August 2018; Accepted: 8 December 2018

\begin{abstract}
This paper reported the results for quantitative determination of acrylamide via hydrolysis process using ultra violet-visible (UVVis) spectrophotometric method. This quantitative determination started with hydrolysing acrylamide in a strong basic condition to yield ammonia and acid salt. The optimum conditions of hydrolysis (concentration of the base used and time for hydrolysis) were also determined. From this study, the optimum conditions to hydrolyse acrylamide were achieved using $6.0 \mathrm{M}$ of sodium hydroxide $(\mathrm{NaOH})$ for 10 minutes. The hydrolysis process was characterised by monitoring the ammonia produced using Nessler's reagent through the formation of yellow colouration in the presence of ammonia. After the optimisation of hydrolysis process, the characterisation of all parameters including concentration of Nessler's reagent used, reproducibility, dynamic range, and interference ions were studied. Linear dynamic ranges from 0-10 ppm acrylamide with limit of detection (LOD) of 0.074 ppm were obtained when $3.0 \mathrm{mM}$ Nessler's reagent was used. The relative standard deviations (RSD) for reproducibility were 2.8-3.3\%. No significant interference from cations such as $\mathrm{Na}^{+}, \mathrm{K}^{+}, \mathrm{Ca}^{2+}$ during quantitative analysis of acrylamide, but ions such as $\mathrm{Fe}^{3+}$ and $\mathrm{NH}_{3}$ affected the analysis.
\end{abstract}

Keywords: acrylamide, hydrolysis, Nessler's reagent

Kajian ini melaporkan keputusan untuk penentuan kuantitatif akrilamida melalui proses hidrolisis dengan kaedah spektofotometrik UV-Nampak (UV-Vis). Penentuan kuantitatif ini dimulai dengan hidrolisis akrilamida dalam keadaan bes kuat dan menghasilkan ammonia dan garam asid sebagai hasil. Keadaan optimum hidrolisis seperti kepekatan bes yang digunakan serta masa hidrolisis optimum telah ditentukan. Daripada kajian, keadaan hidrolisis akrilamida yang optimum ialah menggunakan natrium hidroksida $(\mathrm{NaOH}) 6.0 \mathrm{M}$ dan masa tindak balas selama 10 minit. Proses hidrolisis telah dicirikan dengan memantau ammonia yang terhasil menggunakan reagen Nessler yang akan menghasilkan warna kuning dengan kehadiran ammonia. Setelah mengoptimumkan proses hidrolisis, pencirian semua parameter termasuk kepekatan reagen Nessler yang digunakan, kebolehulangan, julat dinamik, dan ganguan ion telah dikaji. Julat dinamik linear daripada 0-10 ppm akrilamida dengan had pengesanan (LOD) $0.074 \mathrm{ppm}$ telah diperolehi apabila reagen Nessler $3.0 \mathrm{mM}$ digunakan. Sisihan piawai relatif (RSD) untuk kebolehulangan telah diperolehi pada julat 2.8-3.3\%. Kation seperti $\mathrm{Na}^{+}, \mathrm{K}^{+}, \mathrm{Ca}^{2+}$ tidak memberikan gangguan yang ketara pada analisis kuantitatif akrilamida, tetapi ion seperti $\mathrm{Fe}^{3+}$ and $\mathrm{NH}_{3}$ telah mengganggu analisis ini.

Kata kunci: akrilamida, hidrolisis, reagen Nessler 


\section{Introduction}

In 2002, high levels of acrylamide were detected in heat-treated potato products and other baked products as reported by Swedish National Food Authority [1]. Formation of acrylamide in food occurs via reaction between reducing sugar such as glucose and amino acid asparagine at high temperature, known as Maillard reaction [2]. This toxic compound is also found in various carbohydrate-rich products such as French fries, potato crisps, cereals, bread and etc. The levels of acrylamide have been found up to $4 \mathrm{mg} / \mathrm{kg}$ in potato crisps as reported by Erickson [3]. Research done by Dybing et al. revealed that the average consumption of acrylamide for adults were $0.3-0.6 \mu \mathrm{g} / \mathrm{kg}$ body weight while higher exposure for children and adolescents $(0.4-0.6 \mu \mathrm{g} / \mathrm{kg}$ body weight) [4]. This is due to the eating habits of children as they tend to consume more acrylamide-rich foods such as French fries and potato chips. The International Agency for Research on Cancer classified acrylamide as a neurotoxin (probable human carcinogen compound) due to its ability to form adducts with haemoglobin [5].

The conventional methods to determine acrylamide in foods are high-performance liquid chromatography (HPLC), gas chromatography-mass spectrometry (GC-MS) and other chromatographic methods. These chromatographic methods are time consuming, costly, and required high laboratory skills. Moreover, complicated sample preparation and derivatization of acrylamide e.g. bromination are laborious. Besides that, these techniques are not suitable for in-situ analysis due to the large size of the instruments.

Enzyme-linked immunosorbent assay (ELISA) technique has been developed for quantification of acrylamide. Specific antibody is required for detecting acrylamide due to its low molecular mass [6, 7]. The reported limits of detection (LODs) using ELISA techniques were very low apart from, complicated and time consuming procedures to produce antibodies which are among several issues for this technique.

$\mathrm{Hu}$ et al. developed a method for acrylamide detection based on the acrylamide-induced distance increase between quantum dots [8]. The principle of this detection method is distance-dependent fluorescence changes caused by acrylamide polymerization. Fluorescence intensity increases with the presence of acrylamide due to the increase in distance between quantum dots. However, the responded linear range $\left(3.5 \times 10^{-5}\right.$ to $\left.3.5 \mathrm{~g} / \mathrm{L}\right)$ and $\mathrm{LOD}\left(3.5 \mathrm{x} 10^{-5}\right.$ $\mathrm{g} / \mathrm{L})$ were high.

There are some publications reported on voltametric determination of acrylamide [9-13]. Acrylamide forms adduct with haemoglobin and hence alter the electro-activity of haemoglobin. In spite of the low LOD (in nM), the sensors still need to undergo electrode clean-up process, and the modified electrodes must be stored at low temperature $\left(4{ }^{\circ} \mathrm{C}\right)$. Besides that, the immobilized haemoglobin is not stable due to its short shelf life (only 14 days).

Some researchers reported on potentiometric biosensor of acrylamide degradation using microbial cells. Silva et al. hydrolysed acrylamide to acrylic acid and ammonia using Pseudomonas aeruginosa, prior detection using ammonium-ion selective electrode $[14,15]$. Meanwhile, Ignatov et al. used oxygen electrode to test the respiration of Brevibacterium sp. cells in acrylamide solution [16, 17]. Although these sensors are selective towards acrylamide, but are able to detect acrylamide in most of the real food samples due to the high detection limits (in $\mathrm{mM}$ ).

Some bio-molecules such as cells have been used for quantitative determination of acrylamide. Hasegawa et al. developed a sensor based on the ability of acrylamide to create stress onto the cells. The bacterial cells release fluorescence with the present of acrylamide [18]. Some electrochemical sensors based on deoxyribonucleic acid (DNA) have been developed to detect acrylamide [19, 20]. These sensors are based on the changes of guanine's current signal due to the formation of acrylamide adduct with DNA. Besides that, electrochemical characteristics of some living cells are used in the assessment of this cytotoxicity compound. PC-12 cell are immobilised on glassy carbon electrode (GCE) modified with graphene oxide and gold nanoparticles [21]. With the present of acrylamide, PC-12 cells are stimulated by acrylamide and reduced the peak current. However, the major reported disadvantages of this method were high linear range (in $\mathrm{mM}$ ) and LOD. 
To date, the optical acrylamide detection especially colorimetric is yet to be fully explored. Current fluorometric methods for detection of acrylamide still required the polymerization process and are not suitable for in-situ analysis. Therefore, there is a need to develop a new colorimetric method for acrylamide screening.

Optical determination is the easiest field screening on the presence of acrylamide compound in food samples due to obvious colour changes observed via naked eyes. Based on this reason, it is suitable for in-situ analysis. In this research, acrylamide was hydrolysed to its corresponding salt and ammonia. The level of ammonia produced was determined using Nessler's reagent to produce mercury (II) amido-iodine complex (yellow colouration) in basic condition. The overall reactions are shown in Equations 1 and 2, respectively.

$$
\begin{aligned}
& \mathrm{CH}_{2} \mathrm{CHC}(\mathrm{O}) \mathrm{NH}_{2}+\mathrm{NaOH} \rightarrow \mathrm{CH}_{2} \mathrm{CHC}(\mathrm{O}) \mathrm{ONa}+\mathrm{NH}_{3} \\
& 2\left(\mathrm{HgI}_{4}\right)^{2-}+\mathrm{NH}_{3}+3 \mathrm{OH}^{-} \rightarrow \mathrm{HgO} \cdot \mathrm{Hg}\left(\mathrm{NH}_{2}\right) \mathrm{I}+7 \mathrm{I}^{-}+3 \mathrm{H}_{2} \mathrm{O}
\end{aligned}
$$

The aim of this research is to explore a new optical method in quantifying the level of acrylamide in food sample.

\section{Chemical and instrumentation}

\section{Materials and Methods}

Acrylamide $99 \%$ and ammonium chloride $\left(\mathrm{NH}_{4} \mathrm{Cl}\right) 99.5 \%$ were supplied by Sigma. Mercury (II) iodine $99 \%\left(\mathrm{HgI}_{2}\right)$ was obtained from BDH. Potassium iodide (KI) $99.5 \%$, sodium hydroxide $(\mathrm{NaOH}) 99 \%$, and potassium chloride (KCl) $99 \%$ were purchased from Systerm. Calcium chloride $\left(\mathrm{CaCl}_{2}\right) 95 \%$ was supplied by $\mathrm{HmbG}$ Chemicals. Sodium chloride $(\mathrm{NaCl}) 99 \%$ and iron (II) chloride hexahydrate $\left(\mathrm{FeCl}_{2} \cdot 6 \mathrm{H}_{2} \mathrm{O}\right) 99 \%$ were obtained from Acros. Varian Cary-50 was used for all absorbance measurements.

\section{Characterisation of base hydrolysis process towards acrylamide}

The condition for base hydrolysis process of acrylamide was optimised in terms of concentration of base used and time taken for hydrolysis. Acrylamide stock solution (100 ppm) was prepared by dissolving $0.01 \mathrm{~g}$ acrylamide powder in deionised water inside a volumetric flask and topped to $100 \mathrm{~mL}$. Lower concentrations of acrylamide solutions were prepared by appropriate dilutions from stock solution.

The optimum molarity of base needed was tested by injecting $2 \mathrm{~mL}$ acrylamide solution ( $5 \mathrm{ppm}$ ) into various concentrations of $\mathrm{NaOH}(0-8 \mathrm{M})$, leaving the mixture for 15 minutes. Then, the Nessler's reagent was added into the hydrolysed acrylamide solution to form yellow complex called mercury (II) amido-iodine. In this study, $2 \mathrm{~mL}$ of hydrolysed acrylamide solution was added with $985 \mu \mathrm{L}$ water and $40 \mu \mathrm{L}$ of Nessler's reagent. The absorbance of the complex was obtained using UV-Vis spectrophotometer at the wavelength of $420 \mathrm{~nm}$. As for the control, same protocols were repeated using water in substitution for acrylamide solution.

The hydrolysis of $2 \mathrm{~mL}$ acrylamide solution (5 ppm) injected with $6 \mathrm{M} \mathrm{NaOH}$ at different time were recorded. Next, the Nessler's reagent was added into hydrolysed acrylamide solution and the absorbance was measured.

\section{Concentration optimisation of Nessler's reagent}

The concentration of Nessler's reagent used in the solution was optimised. The formation of Nessler's complex was tested using various ratios of $\mathrm{HgI}_{2}$ to KI. Sonication was applied to homogenise the solution during solution preparation. As the optimum ratio of $\mathrm{HgI}_{2}$ and $\mathrm{KI}$ was obtained to form Nessler's complex, the optimum concentration of Nessler's reagent was determined by adding different concentrations of Nessler's reagent into the hydrolysed acrylamide solution. The absorbance of mercury(II) amido-iodine complex was measured using UV-Vis spectrophotometer.

\section{Quantitative determination of acrylamide in solution}

The reproducibility of this method was studied using eight different samples (same concentration of analyte and reagent). The absorbance value of mercury(II) amido-iodine complex was determined using UV-Vis spectrophotometer. The concentrations of acrylamide tested were 2 and $4 \mathrm{ppm}$. 
The dynamic range was studied to determine the range of concentration for acrylamide which fulfil the Beer's law. Acrylamide solution was hydrolysed using $6.0 \mathrm{M} \mathrm{NaOH}$ for 10 minutes. The ammonia produced was determined using $3.0 \mathrm{mM}$ Nessler's reagent and left for 5 minutes for the formation of mercury(II) amido-iodide complex. The absorbance of the complex was measured using UV-Vis spectrophotometer at the wavelength of $420 \mathrm{~nm}$. The concentrations of acrylamide tested were $0-30 \mathrm{ppm}$.

The effects of some interference cations such as $\mathrm{Na}^{+}, \mathrm{K}^{+}, \mathrm{Ca}^{2+}, \mathrm{Fe}^{2+}$, and $\mathrm{NH}_{3}$ present in acrylamide solution were also studied. The relative ratios of acrylamide solutions (without and with interference ions) were determined to study the effects and levels of interference. The effects of interference were determined based on the differences in absorbance values obtained from pure acrylamide solution and the acrylamide solution containing interference ions. If the difference is more than $10 \%$, therefore the presence of interference ions is considered to affect the system.

\section{Characterisation of base hydrolysis process towards acrylamide}

In this study, $\mathrm{NaOH}$ serves two purposes, as the catalyst for base hydrolysis and to create a basic condition for the formation of mercury(II) amido-iodine complex as shown in Equations 1 and 2. Acrylamide, as a primer amide undergoes hydrolysis in basic condition. As shown in Figure 1, 6.0 M of $\mathrm{NaOH}$ is needed to hydrolyse acrylamide solution since acrylamide is a stable acid derivative group and requires stronger condition to hydrolyse. Figure 2 shows the completed base hydrolysis process of acrylamide in solution after 10 minutes.

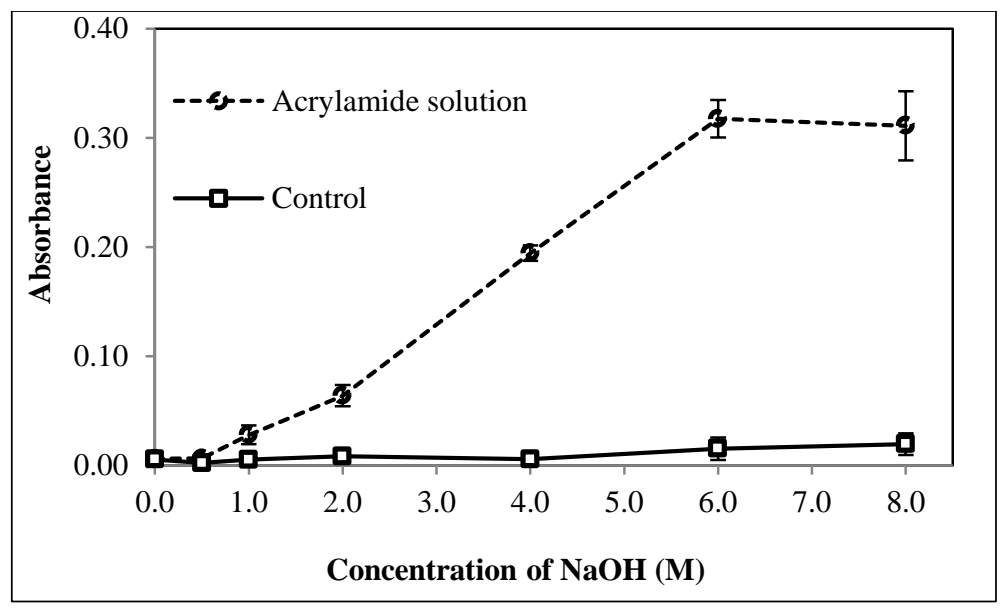

Figure 1. Absorbance of mercury(II) amido-iodine formed after acrylamide being hydrolysed by various concentration of $\mathrm{NaOH}$

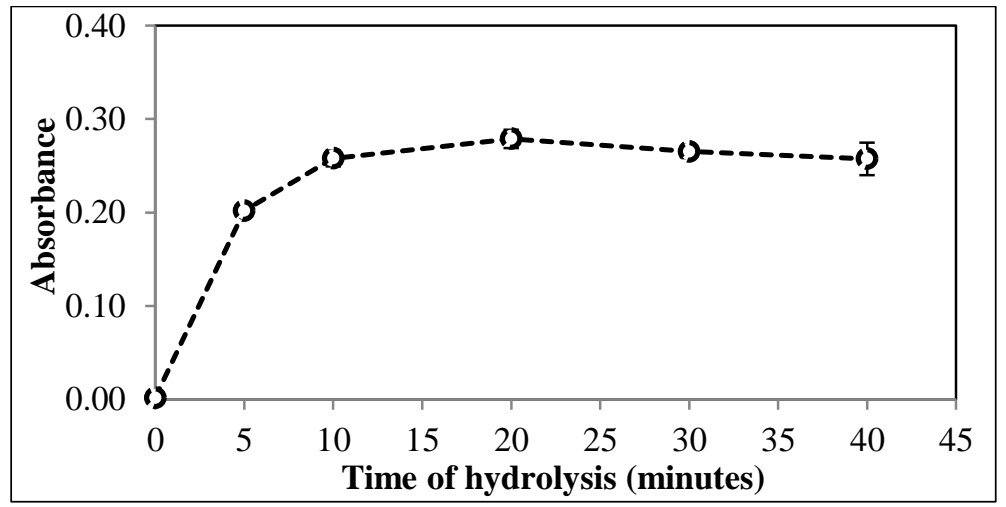

Figure 2. Absorbance of mercury(II) amido-iodine complex with acrylamide hydrolysed in various time measuring at wavelength of $420 \mathrm{~nm}$ 
A study done by Paleologos and Kontominas reported that heating acrylamide at $70{ }^{\circ} \mathrm{C}$ in $5 \mathrm{M}$ sulphuric acid for 6 hours or $4 \mathrm{M} \mathrm{NaOH}$ for 1 hour were able to completely convert acrylamide into its acid derivative [22].

\section{Concentration optimisation of Nessler's Reagent}

The Nessler's reagent is also known as potassium tetraiodomercurate(II) with yellow appearance and consists of two salts $\left(\mathrm{HgI}_{2}\right.$ and $\left.\mathrm{KI}\right)$. From Equation 3, the optimum molar ratio $\left(\mathrm{HgI}_{2}: \mathrm{KI}\right)$ in forming Nessler's reagent is 1:2. From Figure 3, the optimum concentrations of $\mathrm{HgI}_{2}$ and $\mathrm{KI}$ are $0.075 \mathrm{M}$ and $0.15 \mathrm{M}$, respectively. These results fulfilled the theoretical molar ratio of 1:2 to form Nessler's reagent. $\mathrm{HgI}_{2}$ is hardly soluble in water and needs to be added into KI solution to form Nessler's reagent. When $0.075 \mathrm{M} \mathrm{HgI}_{2}$ and less than $0.15 \mathrm{M} \mathrm{KI}$ used, some of the $\mathrm{HgI}_{2}$ remain insoluble in the solution. Therefore, the formation of Nessler's reagent is not completed. This is the reason for not investigating the concentration of KI less than $0.15 \mathrm{M}$ as shown in Figure $3 \mathrm{~b}$. The plateau result from Figure $3 \mathrm{~b}$ shows that the concentration of KI is not affecting the formation of Nessler's reagent when the molar ratio with $\mathrm{HgI}_{2}$ is equal or bigger than 2. Figure 4 shows that the optimum concentration of reagents used in this analysis as $3.0 \mathrm{mM}$.

$$
\mathrm{HgI}_{2}+\mathrm{KI} \rightarrow \mathrm{K}_{2}\left[\mathrm{HgI}_{4}\right]
$$
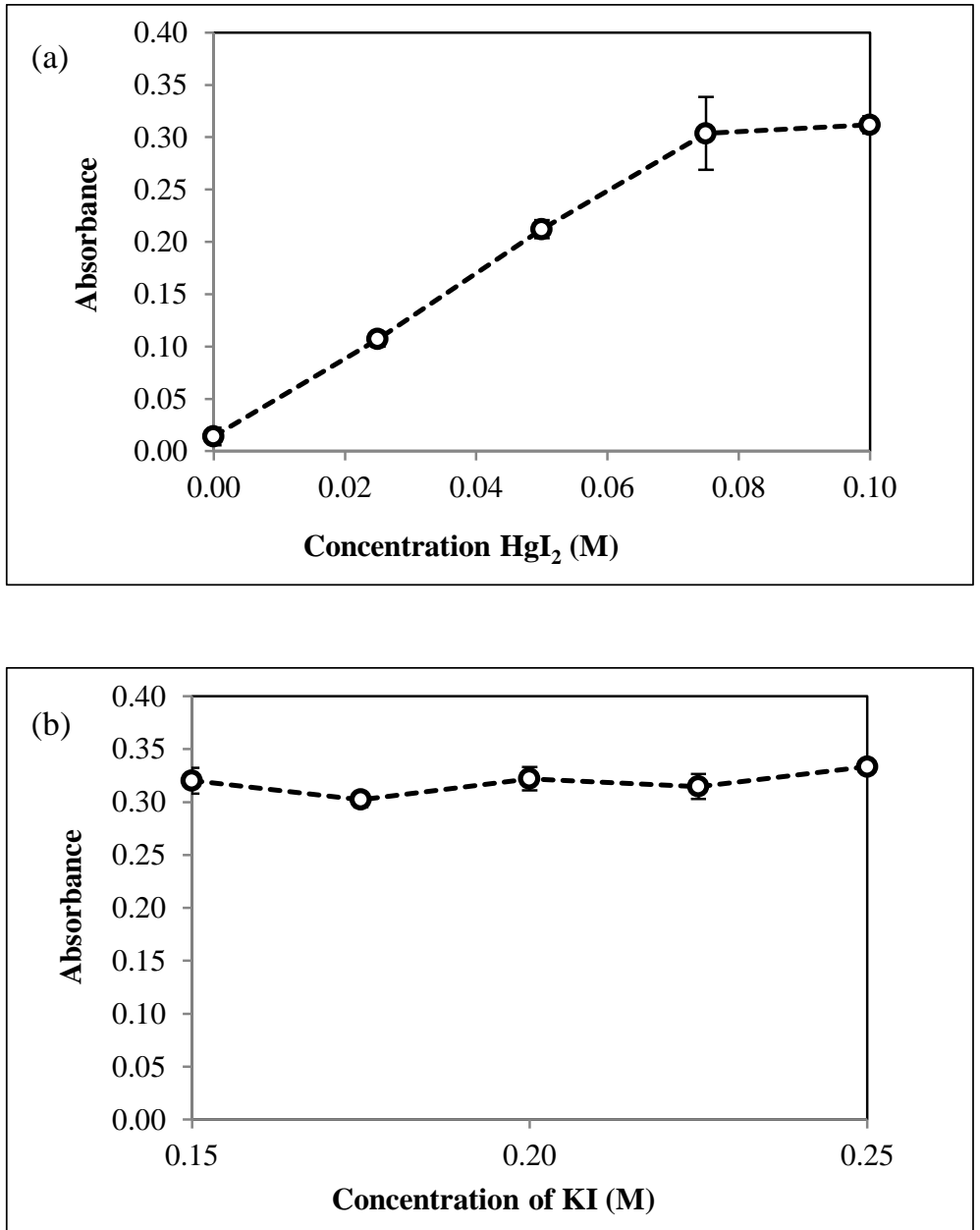

Figure 3. Absorbance of complex formed from hydrolysed acrylamide solution (5 ppm) with $\mathrm{HgI}_{2}$ and $\mathrm{KI}$ in various concentrations 


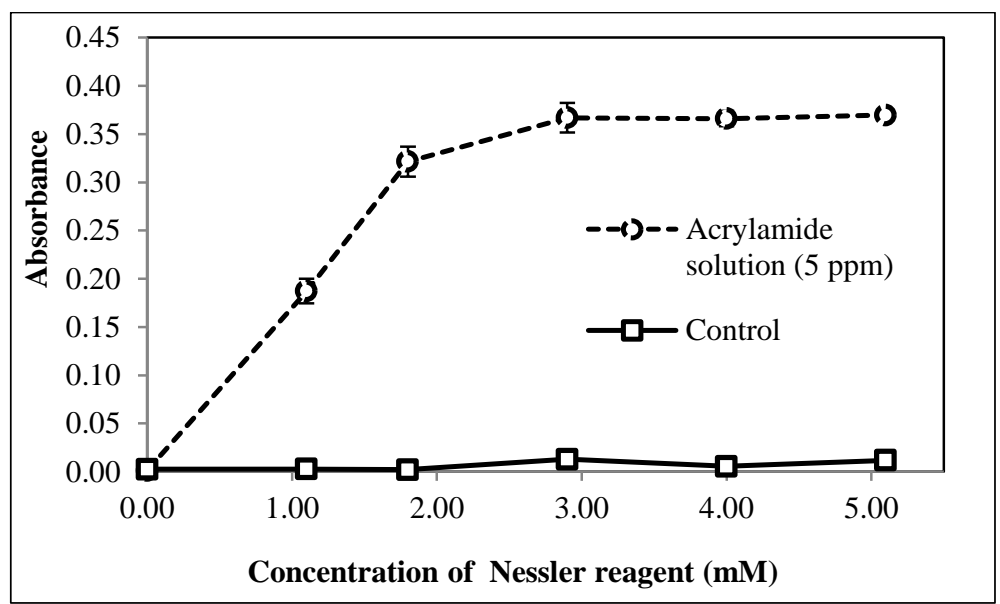

Figure 4. The effect of Nessler's reagent concentration in the detection of hydrolysed acrylamide solution. The absorbance was measured in at wavelength of $420 \mathrm{~nm}$

\section{Quantitative determination of acrylamide in solution}

The reproducibility of this method enables the same experimental procedures being repeated. As shown in Figure 5, this method produced a good reproducibility where the RSD values were 2.8-3.3\%. This result is as comparable to previous studies with reported RSD values of 3.17-6.15\% [23].

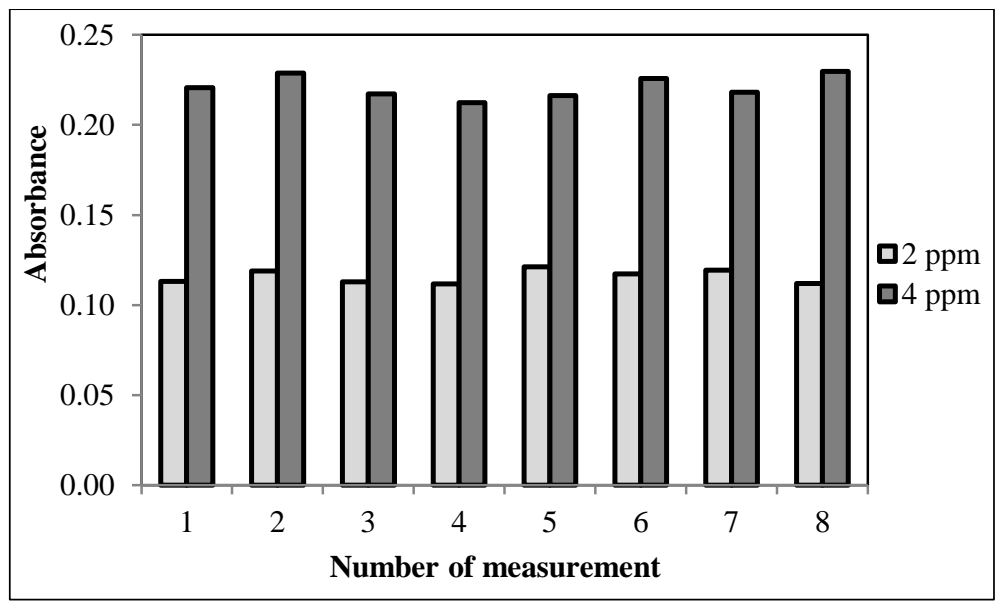

Figure 5. The reproducibility of mercury(II) amido-iodine complex formation at two different acrylamide concentrations after hydrolysis process

The absorbance of mercury(II) amido-iodide increased with the increasing concentration of acrylamide as shown in Figure 6. This is due to the increase in ammonia produced during hydrolysis, hence it is expected that more mercury(II) amido-iodine complex are formed as the absorbance increase. A linear dynamic range was obtained with the acrylamide range of $0-10 \mathrm{ppm}$. The calculated LOD for this method (the concentration of sample that yields a detector equal to three times the detector noise) was $0.074 \mathrm{ppm}$. This method performs better when compared with the work done by Silva et al. [14] where amidase was used to hydrolyse acrylamide and the generated ammonia was detected using ion selective electrode. The reported dynamic range was 7.1-284.3 ppm with the LOD of $3.2 \mathrm{ppm}[14]$. 


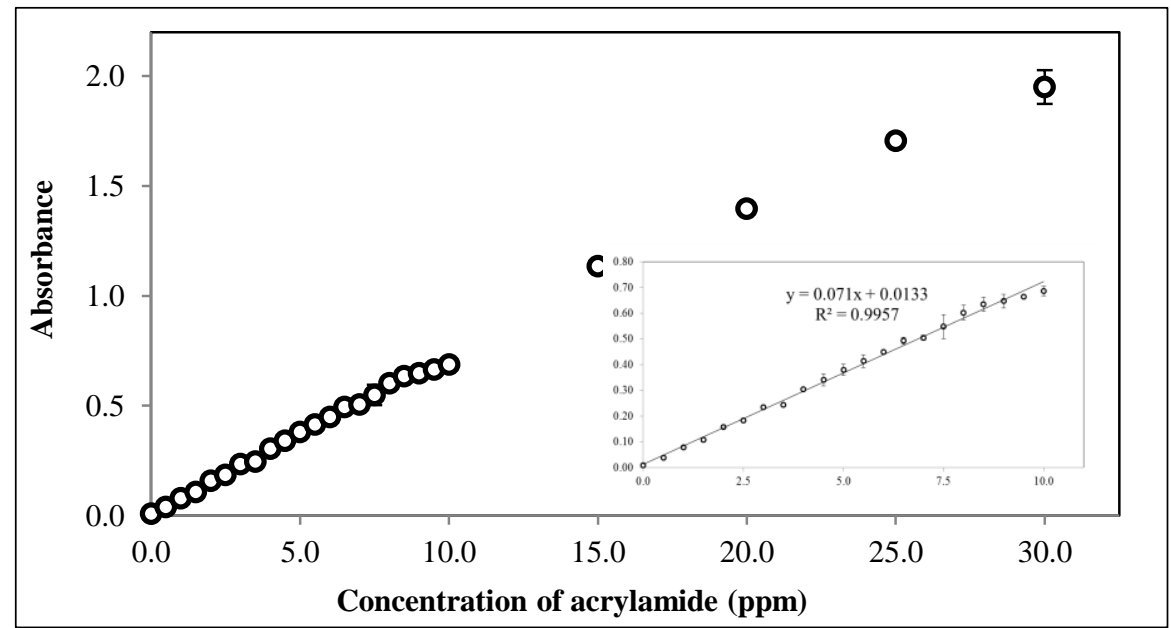

Figure 6. The response of hydrolysed acrylamide in the presence of Nessler's reagent. Absorbance measured in wavelength of $420 \mathrm{~nm}$

Result for the studies of interference ions is shown in Table 1 . Cations such as $\mathrm{Na}^{+}, \mathrm{K}^{+}$, and $\mathrm{Ca}^{2+}$ were not showing any significant interference. However, $\mathrm{Fe}^{3+}$ ion interfered when the ratio of acrylamide: interference ion greater than 1:10. This is because $\mathrm{Fe}^{3+}$ ion involved in two reactions system. First, the hydrolysis of $\mathrm{Fe}^{3+}$ ion in a base to form ferum(III) hydroxide will turns into darker colour. Second, the measured absorbance reveals that the presence of $\mathrm{Fe}^{3+}$ ion in the solution contributes to the same colour as the complex. This study also shows that Nessler's reagent is more sensitive towards $\mathrm{NH}_{3}$ even at low concentration.

Table 1. Effect of interference ions in the detection of acrylamide

\begin{tabular}{lccccc}
\hline \multirow{2}{*}{ Concentration Ratio } & \multicolumn{5}{c}{ Relative Ratio (\%) } \\
\cline { 2 - 6 } & $\mathbf{N a}^{+}$ & $\mathbf{K}^{+}$ & $\mathbf{C a}^{2+}$ & $\mathbf{F e}^{\mathbf{3 +}}$ & $\mathbf{N H}_{\mathbf{3}}$ \\
\hline $1: 0.1$ & -2.17 & -4.97 & -4.70 & -9.49 & 51.27 \\
$1: 1$ & -2.58 & -6.03 & -2.98 & 4.04 & 437.89 \\
$1: 10$ & -5.29 & -2.50 & -5.78 & 12.16 & 4051.35 \\
\hline
\end{tabular}

\section{Conclusion}

Optical quantitative determination of acrylamide based on Nessler's reagent was studied. Acrylamide undergoes hydrolysis process to produce ammonia and corresponding acid salt. The concentration of base used and time for hydrolysis were determined and optimised. Nessler's reagent was chosen as it performs well in the formation of mercury(II) amido-iodine with ammonia. In this study, the generated ammonia after hydrolysis is directly proportional with acrylamide in the solution. Therefore, this base hydrolysis process for acrylamide explored in this study is considered to be a potential quantification of acrylamide. Thus, this study can be explored further to develop an optical sensor.

\section{Acknowledgement}

The authors gratefully acknowledge the financial support received from the Ministry of Education to Universiti Sains Islam Malaysia through research grant USIM/FRGS-FST-5-50311 and Universiti Kebangsaan Malaysia via grants DIP-2014-016 and DPP-2015-064. We would also like to acknowledge the Ministry of Higher Education for the MyBrain 15 scholarship to Yee-May Chong. 


\section{References}

1. Tareke, E., Rydberg, P., Karlsson, P., Eriksson, S. and Törnqvist, M. (2002). Analysis of acrylamide, a carcinogen formed in heated foodstuffs. Journal of Agricultural and Food Chemistry, 50: 4998-5006.

2. Zyzak, D. V., Sanders, R. A., Stojanovic, M., Tallmadge, D. H., Eberhart, B. L., Ewald, D. K., Gruber, D. C., Morsch, T. R., Strothers, M. A., Rizzi, G. P. and Villagran, M. D. (2003). Acrylamide formation mechanism in heated foods. Journal of Agricultural and Food Chemistry, 51: 4782-4787.

3. Erickson, B. E. (2004). Finding acrylamide. Analytical Chemistry, 76: 247A-248A.

4. Dybing, E., Farmer, P. B., Andersen, M., Fennell, T. R., Lalljie, S. P. D., Müller, D. J. G., Olin, S., Petersen, B. J., Schlatter, J., Scholz, G., Scimeca, J. A., Slimani, N., Törnqvist, M., Tuijtelaars, S. and Verger, P. (2005). Human exposure and internal dose assessments of acrylamide in food. Food and Chemical Toxicology, 43: 365410.

5. IARC (1994). International Agency for Research on Cancer, Lyon, France: pp. 389-433.

6. Preston, A., Fodey, T. and Elliott, C. (2008). Development of a high-throughput enzyme-linked immunosorbent assay for the routine detection of the carcinogen acrylamide in food, via rapid derivatisation pre-analysis. Analytica Chimica Acta, 608: 178-185.

7. Zhou, S., Zhang, C., Wang, D. and Zhao, M. (2008). Antigen synthetic strategy and immunoassay development for detection of acrylamide in foods. Analyst, 133: 903-909.

8. Hu, Q., Xu, X., Li, Z., Zhang, Y., Wang, J., Fu, Y. and Li, Y. (2014). Detection of acrylamide in potato chips using a fluorescent sensing method based on acrylamide polymerization-induced distance increase between quantum dots. Biosensors and Bioelectronics, 54: 64-71.

9. Stobiecka, A., Radecka, H. and Radecki, J. (2007). Novel voltammetric biosensor for determining acrylamide in food samples. Biosensors and Bioelectronics, 22: 2165-2170.

10. Krajewska, A., Radecki, J. and Radecka, H. (2008). A voltammetric biosensor based on glassy carbon electrodes modified with single-walled carbon nanotubes/hemoglobin for detection of acrylamide in water extracts from potato crisps. Sensors, 8: 5832-5844.

11. Garabagiu, S. and Mihailescu, G. (2011). Simple hemoglobin-gold nanoparticles modified electrode for the amperometric detection of acrylamide. Journal of Electroanalytical Chemistry, 659: 196-200.

12. Batra, B., Lata, S., Sharma, M. and Pundir, C. S. (2013). An acrylamide biosensor based on immobilization of hemoglobin onto multiwalled carbon nanotube/copper nanoparticles/polyaniline hybrid film. Analytical Biochemistry, 433: 210-217.

13. Batra, B., Lata, S. and Pundir, C. S. (2013). Construction of an improved amperometric acrylamide biosensor based on hemoglobin immobilized onto carboxylated multi-walled carbon nanotubes/iron oxide nanoparticles/chitosan composite film. Bioprocess and Biosystems Engineering, 36: 1591-1599.

14. Silva, N., Gil, D., Karmali, A. and Matos, M. (2009). Biosensor for acrylamide based on an ion-selective electrode using whole cells of Pseudomonas aeruginosa containing amidase activity. Biocatalysis and Biotransformation, 27: 143-151.

15. Silva, N. A. F., Matos, M. J., Karmali, A. and Racha, M. M. (2011). An electrochemical biosensor for acrylamide detection: Merits and limitations. Portugaliae Electrochimica Acta, 29: 361-373.

16. Ignatov, O. V., Rogatcheva, S. M., Vasil'eva, O. V. and Ignatov, V. V. (1996). Selective determination of acrylonitrile, acrylamide and acrylic acid in waste waters using microbial cells. Resources, Conservation and Recycling, 18: 69-78.

17. Ignatov, O. V., Rogatcheva, S. M., Kozulin, S. V. and Khorkina, N. A. (1997). Acrylamide and acrylic acid determination using respiratory activity of microbial cells. Biosensors and Bioelectronics, 12: 105-111.

18. Hasegawa, K., Miwa, S., Tajima, T., Tsutsumiuchi, K., Taniguchi, H. and Miwa, J. (2007). A rapid and inexpensive method to screen for common foods that reduce the action of acrylamide, a harmful substance in food. Toxicology Letters, 175: 82-88.

19. Qiu, Y., Qu, X., Dong, J., Ai, S. and Han, R. (2011). Electrochemical detection of DNA damage induced by acrylamide and its metabolite at the graphene-ionic liquid-Nafion modified pyrolytic graphite electrode. Journal of Hazardous Materials, 190: 480-485.

20. Li, D., Xu, Y., Zhang, L. and Tong, H. (2014). A label-free electrochemical bopsensor for acrylamide based on DNA immobilized on graphene oxide-modified glassy carbon electrode. International Journal of Electrochemical Science, 9: 7217-7227. 
21. Sun, X., Ji, J., Jiang, D., Li, X., Zhang, Y., Li, Z. and Wu, Y. (2013). Development of a novel electrochemical sensor using pheochromocytoma cells and its assessment of acrylamide cytotoxicity. Biosensors and Bioelectronics, 44: 122-126.

22. Paleologos, E. K. and Kontominas, M. G. (2005). Determination of acrylamide and methacrylamide by normal phase high performance liquid chromatography and UV detection. Journal of Chromatography A, 1077: 128135.

23. Chong, Y.-M., Ahmad, M., Heng, L. Y., Kusnin, N. and Shukor, M. Y. A. (2017). Acrylamide optical sensor based on hydrolysis using Bacillus sp. strain ZK34 containing amidase properties. Sains Malaysiana, 46: 15571563. 